\title{
Teaching Mathematical Problem-Solving with the Brain in Mind: How can opening a closed problem help?
}

ANDRÁs AMBRUs ${ }^{1}$

$\approx$ In the international literature, increasing numbers of articles and books are published about teaching and learning, with the brain in mind. For a long time, I have been sceptical about this question. However, seeing many unresolved issues in the teaching and learning of mathematics, I slowly started to study the relevant literature and have attempted to implement some ideas in my teaching. In this article, I will report on my experience with a selected mathematical problem in mathematics lessons and group study sessions; I will demonstrate how I modified the problem, based on my experience with the students, and I will reflect on my studies of brain-based mathematics teaching and learning.

Keywords: problem solving, brain based learning, working memory, open problems, representations, students' activity 


\section{Učenje reševanja matematičnih problemov z upoštevanjem možganov: kako lahko pomaga odpiranje zaprtega problema?}

ANDrás Ambrus

$\propto V$ mednarodni literaturi narašča število objavljenih člankov in knjig o poučevanju in učenju, ki upoštevata delovanje možganov. Dolgo časa sem bil skeptičen do tega vprašanja. Vendar pa sem ob opažanju veliko nerešenih težav pri poučevanju in učenju matematike počasi začel analizirati relevantno literaturo in skušal vpeljati nekaj idej v svoje poučevanje. $\mathrm{V}$ prispevku bom predstavil svoje izkušnje $\mathrm{z}$ izbranim matematičnim problemom pri urah matematike in skupinskih študijskih srečanjih. Pokazal bom, kako sem na podlagi svojih izkušenj s študenti problem modificiral, reflektiral pa bom tudi svoj študij poučevanja in učenja matematike ob upoštevanju delovanja možganov.

Ključne besede: reševanje problemov, učenje na podlagi možganov, delovni spomin, odprti problemi, prikazi, aktivnost učencev 


\section{Introduction}

For a long time in the Hungarian teaching practices of mathematics, the scientific aspect of mathematics dominated, while the psychological, pedagogical, social, biological aspects were mostly neglected. It is not surprising that in Hungarian mathematics curricula and in the mathematics textbooks (including in lower grades) there is a chapter with the title 'Sets. Logic', which cannot be found in other European and American curricula and mathematics textbooks. In short, in Hungarian mathematics teaching, the symbolic, abstract and verbal aspects are dominant.

Regarding mathematical problems and tasks, the so-called closed problems are predominantly used. I can characterise our mathematics teaching by quoting the opinion of Laurinda Brown, who, after numerous visits to Hungarian secondary schools, summarised her experiences in the following way: 'You in Hungary are teaching mathematics; we in England children'.

Another main characteristic of Hungarian mathematics teaching is the fostering of talented pupils, which is in the centre of mathematics teaching. Hungary is a small country from which many world famous mathematicians come. The idea is that such a small country must honour its talent, because they can contribute in a great manner to the development of our country. A direct consequence of focusing mainly on fostering talented students is that $90 \%$ of the students suffer from this situation. Teaching not only the rather talented but also average students, I slowly started to seek some possibilities to help the average pupils. Many books and articles have been published recently on the topic of learning with a specific focus on how the brain works, which can be also applied for mathematics education. Based on my studies, I started to change my mathematics teaching style.

In this article, I will report about my experience with a selected problem, which was formulated and used in Hungarian mathematics teaching in a closed form. However, seeing the immense difficulties my students had, I opened the problem. I have fifty years mathematics teaching experience; nevertheless, I think sometimes it may be appealing to watch and listen to other experts. In terms of research method, we may classify this study as a case study, but I will refer not only to the analysed experience with my students attending my mathematics group study sessions but also to my former class teaching experience. The question I wanted to study is whether it is possible to that more students solve the problem individually or with a small amount of help. 


\section{Some theoretical considerations}

I use the term 'open problem' for problems in which at least one of the three basic notions (initial state, transformation (solution) steps, and goal state) is not exactly determined. We speak about 'open-ended problems' if the goal state is not determined. In this sense, many Hungarian textbook and task collection tasks are open problems because, although their starting situation and goal situation are explicitly given, finding the solution path is a quite difficult task. Our closed problem was transformed into an open-ended problem.

\section{How can the teacher think about mathematics?}

Mathematicians view their subject from any one of three different perspectives: Platonist, Formalist, or Intuitionist.

Platonist: Mathematics exists in an abstract plane. Objects of mathematics are as real as everyday life. Mathematics reality exists outside the human mind. Mathematicians' function is to discover or observe mathematical objects.

Formalist: Mathematics is a game in which one manipulates symbols in accordance with precise formal rules. Mathematical objects have no relation to reality and are solely a set of symbols that satisfy the axioms and theorems of geometry.

Intuitionist: Mathematical objects are solely constructions of the human mind. Mathematics does not exist in the real world, but only in the brain of the mathematician who invents it.

Whichever perspective a teacher has will likely affect his/her approach to presenting mathematics in the classroom. (Sousa, 2008)

\section{Recent discoveries about the nature of mind}

1. The embodiment of mind. The detailed nature of our bodies, our brains and our everyday functioning in the world, structures human concepts and human reason. This includes mathematical concepts and mathematical reason.

2. The cognitive unconscious. Most thought is unconscious (not repressed in the Freudian sense) but simply inaccessible to direct conscious introspection. We cannot look directly at our conceptual systems and at our low-level thought processes. This includes most mathematical thought.

3. Metaphorical thought. For the most part, human beings conceptualise abstract concepts in concrete terms, using ideas and modes of reasoning grounded in the sensory-motor system. The mechanism by which the abstract is comprehended in terms of the concrete is called a 'conceptual metaphor'. Mathematical thought also makes use of conceptual metaphor as we realize numbers as points on a line. (Lakoff \& Nunez, 200o) 


\section{Two systems in the brain}

The first system works automatically and extremely fast with little effort. Conscious control is not part of this activity. It has systematic failures. It does not sufficiently understand the rules of logic and statistics. Decisions are based on impressions and feelings.

The second system focuses its attention on mental activities that need effort. Its work is based on the rules of logic and statistics. It is responsible for conscious control, but it is lazy. The first system builds the main source of the second system. If everything is going well, the second system with minimal or no modifications accepts what the first system states. Usually we believe in our impressions, and we act according to our wishes. (Kahneman, 2011)

\section{Memory structures}

Most neuroscientists accept Baddeley's model of memory structures, i.e. perceptual memory, working memory, and long-term memory. In problem solving, the role of the working memory is vital. It is called the 'workbench of our brain'; it is the active problem space. It has four components: the phonological loop to hold and rehearse verbal information, the visual-spatial sketchpad to hold visual and spatial information, the episodic buffer that connects the verbal and visual-spatial information directed by the central executive with the help of the information taken from long term memory and, finally, the central executive is the so-called supervisory attention system, because it monitors and controls the information processing in our brain. Our working memory constructs plans, uses transformation strategies, analogies, metaphors, brings things together in thought, abstracts and externalises mental representations. In problem solving, a student needs a clear mental representation of the task (understanding the problem). While seeking a strategy (solution method), the student needs to hold the conditions and the goal in his memory and, taking this into consideration, he (she) should monitor his (her) progress in the solution, avoid wrong, unsuccessful ideas and control his (her) results. It is exceedingly difficult to make these components appear in class teaching.

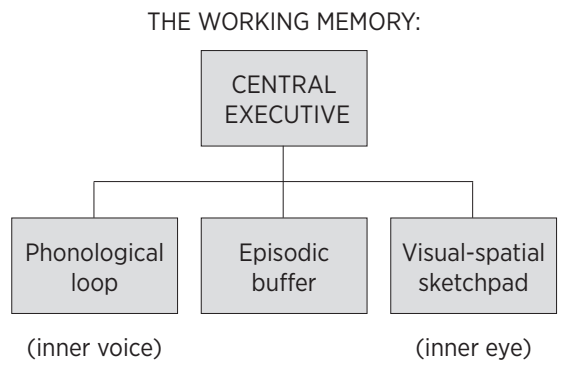


Executive functions: goal setting, planning, organising, prioritising, initiating, holding information, inhibiting irrelevant information, self-monitoring, memorising, self-regulating, representing, problem solving

Limits of WM: very limited capacity holding $7 \pm 2$ info units, time limit: 18-20 sec, goal maintenance, inhibit irrelevant information

\section{Overcoming the limits of Working Memory \\ Chunking.}

The compression of information into larger units; e.g. to remember the number 238465197, it is easier to divide it into groups: $238-465-197$.

Another possibility is connecting the information to previous knowledge. We can build a concrete metaphor to the abstract situation. Applying past knowledge allows the problem to be represented with fewer chunks of information. For example, the Wason-Shapiro problem:

You have four cards, each with a number on one side and a letter on the other side. The cards are displayed with 4, 7, E, X showing. Your task to determine whether the following rule describes these four cards: If a card has an even number on one side, it has a vowel on the other side. Which cards must to be turned over to test the rule? (Sala \& Anderson, 2012)

The problem will be much easier if common knowledge is used:

A certain auto repair shop services Hondas and Buicks. A recall announcement indicates that the accelerator pedals on the Hondas can become stuck, potentially leading to accidents, and therefore warranting repair. Four customer cards are sitting on the desk. Each one indicates the customer's name and the brand on one side and, on the other side whether the accelerator pedal has been checked. The four cards placed on the desk show Honda, Buick, checked and not checked. Which cards need to be turned over?

A problem based on knowledge is much easier to solve than the same problem expressed in an abstract manner. Making the best use of students' knowledge as well as encouraging retention strategies is critical for fostering learning and comprehension.

\section{Using different representations (mental codes)}

We may differentiate between three mental codes: verbal (symbolic), iconic (visual) and motor. We characterise only the third one, because the verbal and visual representations have been frequently discussed. Neuroscientists state that much of what people remember concerns previously performed actions. Actions can improve memory through creating an additional memory code based on motor movements. The advantage of using (if possible) three different 
codes instead only one is that they provide additional opportunities for retrieval. In solving our problem, the students used all three types of representations. Many experimental findings support the view that much of our thinking can be viewed as relieving our perceptual and motor experiences, rather than as a form of internal verbalisation. It is unfortunate that the symbolic, formal, abstract representations are dominant in Hungarian mathematics education.

New mathematical concepts should be presented at three levels: concrete (e.g. manipulative), pictorial (visual) and abstract. Visualisation of mathematical problems through the use of concrete examples and /or representation examples assists many students in mastery at almost every grade level. Manipulatives should be used with learning problems. Teachers should encourage students to visualise problems using manipulatives and then to explain the result to each other. Let students consider the question: 'How can we make mathematics representational?'

As for the memory, it is better to have three different memory traces for the same concept. In this case, the chance for retrieval will be much higher.

From our point of view, enhancing the capacity of working memory vs. freeing some parts of the capacity is relevant. If we use external representations for fixing the data and the goal situation of the problem, we do not need to hold all the relevant information in our working memory.

\section{Goal maintenance}

In the problem-solving process, the maintenance of the goal is extremely important; without it, there is no successful solution. To maintain the goal, inhibiting irrelevant information plays a basic role. The more able students can hold more pieces relevant information in their working memory; the weaker students hold a great of irrelevant information in their working memory, occupying too much capacity. It is an extraordinarily hard and exceptionally long process to teach students to differentiate between relevant and irrelevant information in different contexts and for different tasks. Using external representations may help to focus on the goal, because the data, the given relations between them and the goal may be recorded in students' notebook.

\section{Basic instructional strategies to enhance learning.}

1. Gaining students' attention. No attention, no engagement, no learning!

2. Activating students' prior knowledge and experiences. Having prior knowledge and experience that relate to current learning enhances memory and vice versa. In our case, this was the most difficult phase.

3. Actively involving students in the learning process. Students will be able to 
retain $10 \%$ of what they read, $20 \%$ of what they hear, $30 \%$ of what they see, $50 \%$ of what they see and hear, $70 \%$ of what they say, $90 \%$ of what they say and do. These data show how powerful the hands are in the learning process.

4. Facilitate the ability of students to construct meaning. The mind tends to remember content that is meaningful and well structured. In our case, manipulation with cut-out paper squares gave the meaning of the entire partition process for many students.

5. Students demonstrate their learning. It needs a careful preparation: organising, separating essential vs. nonessential, connecting to previous knowledge, constructing meaning, chunking (compressing information into blocks), summarising, and teaching to take tests. The aim should be the development of the students' self-evaluation, i.e. the ability to reflect on himself (herself) as a learner: How do I plan to learn? How do I monitor my learning? How well did I do? Do I need to make changes? (Banikowski \& Alison, 1999)

\section{Brain-Compatible Guidelines for Math Instruction}

1. Less is more. It is more advisable to develop a true understanding of a few problems rather than assigning many problems.

2. Present Information at Three Levels. (motor, pictorial, abstract-symbolic)

3. Teach the 'Big ideas' in Mathematics. Teaching should address these ideas explicitly.

4. Emphasise Mathematical Patterns.

5. Teach Math Facts to a High Level of Automaticity.

6. Use Novelty to Build on Students' Strengths.

7. Teach Algorithms Explicitly. This statement will be explained in greater detail, because in Hungarian mathematics teaching there exists only one opinion: we shall do mathematics in our head, because it is an abstract science. Bender writes:

'Research has demonstrated the critical importance of automaticity in math facts as one critical basis for increased achievement in higher mathematics. Students can proceed successfully in math only after the math facts are learned at a high level. The use of chants, music, and other novel teaching tactics will enhance memory for facts. These techniques are quite enjoyable and will assist students who learn better by using their strengths in musical intelligence.'

8. Teach to Both Brain Hemispheres.

9. Scaffold the Students' Practice.

10. Understand the Fear and Explore the Beauty. (Bender, 2009) 
These strategies are practical consequences of the nature of the mind (viz. Lakoff and Nunez).

A highly neglected aspect of the development of the brain in Hungarian mathematics teaching. The prefrontal cortex is the part of the frontal lobe that analyses problems, implements and controls non-routine strategies. It develops unusually slowly and is not fully mature until the age of 22-24. Children and adolescents are prone to impulsive decisions while solving problems. Their brains areas have not had much opportunity in school to construct the nonroutine strategies that are needed to override the automated responses.

\section{Experience with a problem}

In Hungarian mathematics textbooks and task collections, and on mathematical university entrance exams, closed problems are dominant. I encountered the following problem in a mathematical task collection: Can we divide a square exactly into 1998 squares without overlapping and without gaps? It was posed in the year 1998. At that time, I taught in a Grade 11 class, and I gave the problem to my students. Nobody was able to start solving it. After my hint: Try to start with small numbers, the students could divide a square into parts, but nobody could find he relationship between the number of parts, i.e. the main idea: if I can divide the square into some parts, three more can be added by dividing one of its sub squares into four parts. The students noticed the main idea 'three more' only with the help of my direct guidance.

Another problem was to find the starting positions. One year later, when I asked my students to divide a square into 1999 squares, they remembered only the problem we had discussed one year earlier, but not the solution method. When I met the author of the task collection, and asked her why she posed the problem in a closed form, she answered: 'The students must know that if in a task there is a question involving a big number, we need to start to prove it for small numbers.' She was a mathematics teacher in a school that specialises in mathematics, where they collect the best of the mathematically talented students. For such students, using this strategy might not cause a problem, but in an average class the situations is quite different.

In the following, I will report my experience of a study session in which the open version of the original problem dominated, and I was working with students of different ages, different abilities and different nations. After I posed the problem to my students, I started to study the neuropsychological literature, beginning with all studies about mathematics. 
The second variation of the original problem:

Try to divide a square into small squares without overlapping and without gaps. Start with small numbers like $2,3,4,5,6,7,8, \ldots$ Try to find a regularity. For which numbers can you make the partition? Justify your general statement. Can you divide a square into 2013 squares?

The third variation of the problem:

You have cut-out paper squares with different side lengths. Try to build bigger squares using these smaller squares without overlapping and without gaps. Record the numbers of the squares with which you were able to build bigger squares in your exercise book. Try to find regularity for the number of building squares. Is it possible to build a square using 2013 smaller squares? Justify your general statement.

\section{Participants}

I posed this problem in different grades, from 5 to 12, of middle and secondary schools and many times for mathematics teacher students at Eötvös Lóránd University Budapest. This year, I had a Polish group with highly talented students and a Finnish group with average ability students in a summer camp. Last time in Hungary, I posed the problem for talented students in a mathematics group study sessions.

I will concentrate only on some questions: curriculum value, representations, automation, emphasising mathematical patterns and the 'Big Idea'.

\section{What is the curriculum value of the problem?}

Our problem may be considered as a competition problem. It is usually posed on Hungarian national mathematics competitions in a closed form using the year of the competition in the question. I wonder why the committees do not formulate the problem in open form. It can be a good investigation problem. The committees' argument is that with investigational problems it is extremely difficult to evaluate the students' solutions. I cannot agree with this, because in the investigation of problems there are more objective criteria that can be precisely evaluated. For example: Is there a systematic trial? Did the solver find a pattern? Could the solver generalise from special cases? Is the generalisation formulated clearly? Is it expressed in symbolic form? Is there a proof for the solver's statement?

We may also pose the problem in a regular mathematics lesson. Many teachers state that this task is not curriculum based. Let us analyse it in more detail. From a geometry perspective, the solution activates the knowledge about 
squares, about perpendicular and horizontal straight lines, area, and similarity. From an arithmetic perspective, the remainders when divided by three play a decisive role; this problem is part of the compulsory curriculum. As an important idea, recursion builds the main solution idea. The 'big idea: three more' in essence is a recursion principle. Geometrically, it is a partition problem, which also plays a crucial role in higher mathematics. From a problem-solving perspective, the open version gives engaging possibilities to practice the following activities: investigate special cases, see (finding) a pattern, generalise, symbolise, conjecture and prove. Based on this analysis, we may pose the problem when teaching the division by three. If we extend the problem to other geometrical figures, it can also be a good project to work on. In this case, we need to take into consideration the materials available on the internet.

\section{Using different representations}

Based on my experience, the paper on which the students work may influence the chance of finding some solution steps. If the students work on plain sheets, it is harder to find any solutions than if they work on square-grid paper sheets. The latter can contribute to some solutions in concrete cases if the students draw along the lines of the grid, as they usually do. Based on our experience, in this case, there is also a need for a teacher's guidance as most student can only see the small squares, which lead to cases of $1,4,9,16,25$, etc.

With cut-out paper squares, every child could find some solutions. Although this version is the reverse of the original problem, based on our experience, it is not a problem for students, and they were able to transform the building strategy into the partition strategy. They drew the cases in their exercise books when they were ready with one case, after looking at the whole figure, they noticed that it can be seen as partition. These activities were necessary for Grade 5 to 8 students, but some of the Finnish students also applied it.

\section{Automation}

There is an old dogma in Hungary: you do not need to learn mathematics, it is enough to understand it. According to this, there is no need for memorisation in mathematics teaching and learning. There is a formula book for secondary school students, containing all necessary formulas, definitions and theorems. In lower grades, there are many diagrams, tables, graphs representing essential geometrical concepts, functions, and theorems with illustrations displayed in the classroom. I observed that the better students also strongly depend on these teaching aids. Based on the results of brain research, the previous dogma should be disposed of. In the case of complex problems, the working 
memory capacity will be overloaded for numerous students, and they will lose the solution path. That is why automation is so vital. In our task, the knowledge about squares with their main characteristics, the rule of division by three and the remainders should be recalled automatically at the correct places.

\section{Using external memory aids}

First, because of the limited working memory capacity, many students cannot perceive the solution path and at which stage they are. To avoid this problem, we usually record the solution steps in a coherent table form. Of course, the following table shows the final version; in the students' trials, quite unsystematic cases are produced. The students have time to experiment with different attempts; young students and typical classes usually needed the teacher's help to direct the recording of the solutions. (Table 1)

\section{Table 1}

\begin{tabular}{lll}
\hline Start number & Found partitions & Generalised case \\
\hline 6 & $9,12,15, \ldots$ & $6+3 n$ \\
\hline 7 & $10,13,17, \ldots$ & $7+3 n$ \\
\hline 8 & $11,14,17, \ldots$ & $8+3 n$ \\
\hline
\end{tabular}

\section{Differentiation}

In the investigated population, I could observe enormous differences. I had two talented students: one is in Grade 9, and another in Grade 10. For them, the original question ('Can we divide a square into 2013 smaller squares without overlapping and without gaps?') was not a problem: they obtained the correct solution in one minute. I had similar results this summer in the mathematics summer camp with talented Polish students. They encountered the problem much earlier and, because they have a very good memory, they remembered it well. For them, the generalisation was quite natural; they could explain the whole solution, including the exceptional cases: 2, 3, 5 .

The Finnish students were the same age (Grade 10), but they could not start to solve the problem. I gave them the second version, and they worked on the third version in groups. To build squares from cut-out paper squares was an immense help for them; this also happened with younger Hungarian students.

\section{Finding the mathematical pattern}

The most difficult step in the solution of our problem was to find a regularity, i.e. to see a pattern. There were some students who could solve the 
problem for cases from six to twenty, without seeing what is common in the special cases. It is not an easy question to decide how much time we should give the students for free trial, without any direct guidance from the teacher. Of course, I went around the classroom and asked the groups how much progress they had made, what they were doing, and sometimes I gave a small hint about what they should try. Another hint concerned the organisation of the solved cases. (See the external memory aids.) The most difficult step for the students was generalising from the special cases. The students in Grades 5, 6 and 7 could formulate their statements with words; for older students, taking the starting numbers into consideration usually caused a problem. At the end, we usually had a discussion, the groups reported on their solutions. This period was good to summarise the most essential steps, solution ideas for which we used the 'Big Idea' terminology. In our problem, 'Three more' was the basic idea (drawing a cross into one sub square dividing it into four smaller squares). In the lesson, this basic idea appeared many times, giving a great opportunity for the students to memorise and remember it. Neurobiologically, the corresponding network between some neurons was enhanced more frequently.

In higher grades, we explicitly discussed and recorded the mathematical idea of recursion.

A common experience was that the students could not give explicit arguments as why it is impossible to divide a square into three or five smaller squares. Younger students simply stated that it was, of course, not possible, while older students' arguments were deficient. In this problem, the cut-out paper squares could help the students understand the situation.

\section{Students demonstrate their learning}

In the last part of the lessons, we attempted to verify what the students had actually understood and learnt. The popular question was: 'Is it possible to implement the partition for last year or next year?' In these cases, students needed to explain in detail what the starting square is and what the concrete partition process leading to the desired number of squares is. It was a good exercise for solving simple equations.

With the talented students, we usually discussed the possible extensions of the original problem: dividing a regular triangle into smaller regular triangles (the 'three more' strategy works here by drawing the midlines into a sub-triangle), dividing a rectangle into rectangles, dividing a rhombus into rhombuses (cross drawing functions in both cases). A more difficult question is the division a cube into smaller cubes. 


\section{Conclusions and suggestions}

From the five instructional strategies (attention, etc.) analysed in the theoretical part, four appeared in the students' work; only activating prior knowledge was not satisfactory.

If we would like the students to notice the idea of 'three more', we should prepare them for it. The following tasks can contribute to it.

1. Counting by three forward, can we reach all natural numbers?

2. Matchstick game: There are 27 (or 26 or 25 ) matchsticks on the table. Two players are playing. The rules of the game: take 1 or 2 matchsticks in each step. (Each player must take away some matchsticks.) The winner is the one who takes the last matchstick. Is there a winning strategy? Which one is better: to be the first or the second player?

3. Investigate the natural numbers based on their remainder after dividing by three. How many classes can you build? What is the difference between neighbouring numbers in one class?

4. How many squares are on the following picture? (Figure 1.)

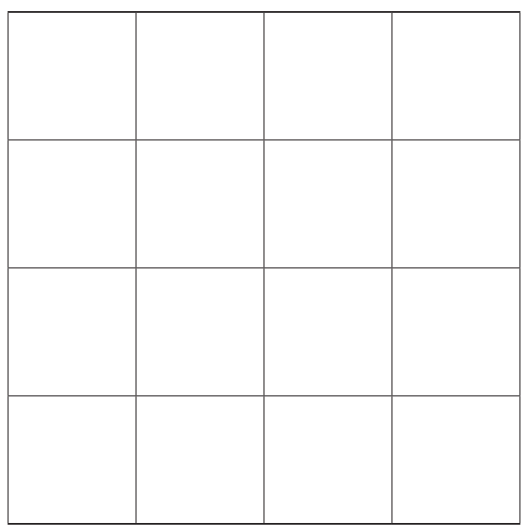

Figure 1.

In this task the students need to see bigger squares containing smaller squares as a whole. It is desirable to investigate the same problem for $5 \times 5,10 \times 10$, $100 \times 100$ squares. With talented students, an $\mathrm{n} \times \mathrm{n}$ square should also be analysed.

Of course, there is not enough time in one lesson to handle so many problems, so some problems were set as homework or as project work (see matchstick problem).

Based on my experiences, I am convinced that mathematics teachers should take the brain-compatible principles and guidelines into consideration. 
It seems that teachers also have different working memory capacities, so we should 'memorise' these strategies and ideas. I think the most relevant strategies are: less is more, emphasising 'Big Ideas', automation, using different representations, and the explicit teaching of problem solving strategies.

Another important issue to take into consideration is the fact that the prefrontal cortex is the part of the frontal lobe, which analyses problems, and implements and controls non-routine strategies. It develops very slowly and is not fully mature until 22-24 year of age. Children and adolescents are prone to impulsive decisions while solving problems. Their prefrontal cortex areas have not had much opportunity in school to construct non-routine strategies that are needed to override the automated responses. When we teach mathematical problem-solving for children with different ages we must take this phenomenon into consideration.

\section{Literature}

Aschraft, M. H., \& Radvansky, G. A. (2010). Cognition. New York: Pearson.

Baddeley, A., Eysenk, M. V., \& Anderson M. C. (2009). Memory. New York: Psychology Press.

Banikowski, A. K. (1999). Strategies to enhance memory based on brain-research. In Focus on

Exceptional Children. Vol.32. Issue 2.

Bender, W. N. (2009). Differentiating Math Instruction. California: Thousand Oaks.

Davidson, J. E., \& Sternberg, R. J. (2003). The Psychology of Problem Solving. Cambridge: Cambridge University Press,

Della Sala, S., \& Anderson, M. (2012). Neuroscience in Education. Oxford: Oxford University Press.

Eysenk, M. V. (2007). Fundamentals of Cognition. New York: Psychology Press.

Gasser, P. (2008). Neuropsychologische Grundlagen des Lehrens und Lernens. Bern: h e p

Bildungsverlag.

Gasser, P. (2010). Gehirngerecht lernen. Bern: h e p Bildungsverlag.

Gathercole, S. E., \& Alloway, T. P. (2009). Working memory and Learning. London: SAGE

Publication.

Kahneman, D. (2011). Thinking, Fast and Slow. New York: Farrar Straus and Giroux.

Lakoff, G., \& Nunez, R. (2000). Where mathematics comes from: how the embodied mind brings mathematics into being. New York: Basic Books.

Meltzer, L. (2007). Executive Function in Education. New York: The Guilford Press.

Nunez, R., \& Freeman, W. J. (Eds.) (1999). Reclaiming Cognition. The primacy of action, intention and emotion. Thorverten, UK: Imprint Academic,

Pinker, S. (1999). How the Mind Works. New York: W. W. Norton Company,

Sammons, L. (2010). Guided Math. A Framework for Mathematics Instruction. Huntington Beach:

Shell Education. 
Small, M. (2012). Good Questions: Great Ways to Differentiate Mathematics Instruction. London:

Teacher College Press.

Small, M., \& Linn, A. (2010). More Good Questions. Great Ways to Differentiate Secondary

Mathematics Instruction. New York: Teacher College Press,

Sousa, D. A. (2008). How the Brain Learns Mathematics. Thousand Oaks: Corwin Press.

Sternberg, R. J., \& Ben-Zeev, T. (1996). The Nature of Mathematical Thinking. Malwah, N.J: Lawrence

Erlbaum Associates.

Ronis, D. (2007). Brain-Compatible Mathematics. London: Corwin Press.

\section{Biographical note}

ANDRás Ambrus, Dr. is an associate professor at Eötvös Lóránd University Budapest, candidate of mathematics $(\mathrm{PhD})$. His main research topic is problem solving in mathematics education. Main publications: Indirect Arguments, Reasons, Proofs in Mathematics Education. (German) Franzbecker Verlag Hildesheim, 1992; Introduction into Didactics of Mathematics, (Hungarian) Eötvös Kiadó Budapest, 1995; and projects: Aktion Österreich-Ungarn Doctor Seminar 2002 - 2005; PDTR (Professional Development of Teacher Researchers) project 2006 - 2008. He is one of the founders of the Mathematics Didactics PhD School at the University of Debrecen; Member of the editorial board of the journal Teaching Mathematics and Computer Science. 